\title{
Procedural control and the proper balance between public and private interests in defamation claims
}

\author{
Richard Hyde*
}

Whilst a great deal has been written about the proper balance between freedom of expression and protection of reputation in defamation law, ${ }^{1}$ the literature has tended to focus on the substantive law, particularly changes wrought by both common $\operatorname{law}^{2}$ and statute. ${ }^{3}$ This article seeks to take a different approach, and to consider how procedural law has been used to balance public and private interests, including its use to balance rights to expression and reputation in defamation claims. Whilst the proposed reforms to dispute resolution in the post-Leveson era may lead to some defamation claims brought against the media being dealt with in a specialised arbitration venue, ${ }^{4}$ the courts will remain central to seeking the important balance between public and private interests. Indeed, it appears that the use of procedural law to seek an appropriate balance between public and private interests arises more often in cases not involving media

* Lecturer in Law, University of Nottingham. Thanks are due to Ashley Savage, Eric Barendt and the anonymous reviewer for their comments on earlier drafts of this article. All websites accessed $19^{\text {th }}$ December 2013.

${ }^{1}$ See e.g. Gavin Phillipson, 'The Global Pariah, the Defamation Bill and the Human Rights Act' (2012) 63(1) Northern Ireland Legal Quarterly 149; Alistair Mullis and Andrew Scott, 'The Swing of the Pendulum: Reputation, Expression and the Re-Centring of English Libel Law' (2012) 63(1) Northern Ireland Legal Quarterly 27.

${ }^{2}$ In particular the innovative Reynolds defence. See Reynolds v Times Newspapers [2001] 2 AC 127; Jameel v Wall Street Journal [2007] 1 AC 359 and Flood v Times Newspapers [2012] 2 AC 273. For commentary see Eric Barendt, 'Balancing Freedom of Expression and the Right to Reputation: Reflections on Reynolds and Reportage' (2012) 63(1) Northern Ireland Legal Quarterly 59.

${ }^{3}$ For example the Defamation Act 1996 and the Defamation Act 2013.

${ }^{4}$ See Sir Brian Leveson, An Inquiry into the Culture, Practices and Ethics of the Press (HMSO, 2012) part K, para 5.4-5.5. 
defendants, which will not in future use the proposed arbitration system, ${ }^{5}$ and which will therefore need to be managed through the court system.

In Part 1 this article briefly argues that an appreciation of the procedural steps taken by courts in defamation cases is essential to understand the balance between public and private interests which they reach. It is argued that it is through procedural case management, to an equal or greater extent than substantive law, that the courts achieve this balance, and that a greater focus on procedural innovation by courts is important in understanding their attitude to defamation actions.

Part 2 turns from the general to the specific and examines at length the procedural methods that the courts use to manage and terminate defamation claims (predominantly libel), critically considering the contribution of each of these to the public interest-private interest orthe expression-reputation balances. The expression-reputation balance is familiar, but the balance between public interest and private interests allows the courts to weigh the public interest in efficient court process against an individual's private interest in resolving a dispute. Whilst a case may be serious to an individual, when balanced against other cases within the systems, it may not be important enough to society to engage the court system. In particular, the possibilities of summary judgement, under both Civil Procedure Rules ('CPRs') Pt24 and Defamation Act 1996 sections $8-10$, and of striking-out a statement of case as an abuse of process, developed in Jameel $v$ Dow Jones ${ }^{6}$ are considered. The development of these procedural controls is analysed, and the role they play in balancing both public and private interest and expression and reputation considered.

\footnotetext{
${ }^{5}$ The proposed arbitration scheme would deal with claims where the defendant is a subscriber to a recognised regulatory body. This would not include private individuals and non-media corporations.

6 Jameel v Dow Jones [2005] QB 946.
} 
Part 3 turns to examine the position of these procedural innovations following the passage of the Defamation Act 2013, particularly the Jameel strike-out, which some have argued has been subsumed into section 1 of the Act. Finally, in Part 4, the article concludes by arguing that more procedural innovation is necessary to ensure that claimants and defendants in defamation actions are dealt with justly, and to ensure that the proper balance between the public and private interests in defamation claims is reached.

\section{1 - The importance of Procedural Innovations in Defamation Cases}

Academic commentary on defamation law has tended to focus on substantive questions. Open an undergraduate textbook on the law of torts, and it is the substantive doctrines that receive coverage. Procedure is barely mentioned, beyond the possibility of trial by jury and consideration of available remedies. ${ }^{7}$ Procedural issues have been left to practitioners to deal with, and matters of procedure receive detailed coverage in practitioner texts. ${ }^{8}$ However, these practitioner texts do not consider the underlying rationales for the procedural actions taken by the courts. The division between substantive and procedural is regrettable, because it is in the procedural field that the courts have made innovative steps to address difficult questions in defamation law, and particularly to address defamation claims that have the potential to chill freedom of speech. This article attempts to close this gap, taking procedural steps seriously in a bid to properly understand how the courts balance public and private interests in defamation cases. It also contributes to the broader debate about the role of procedure in the understanding of the substantive law, arguing that the division of substance and

\footnotetext{
${ }^{7}$ See e.g. W V H Rogers, Winfield and Jolowitz on Tort (18 ${ }^{\text {th }}$ Edn Sweet and Maxwell, 2010) [12-68]-[12-71].

${ }^{8}$ Patrick Milmo and W V H Rogers, Gatley on Libel and Slander (11 ${ }^{\text {th }}$ edn Sweet $\&$ Maxwell, 2008)
} 
procedure is regrettable, and has the potential to lead to an incomplete understanding of the approach taken by courts. ${ }^{9}$

By treating substance and procedure separately, it may be assumed that they deal with separate interests, and do not deal with fundamentally the same questions from different angles and at different stages. Such an assumption would be incorrect. ${ }^{10}$ Procedural law is crafted to achieve the same ends as the rules of substantive law. Both substantive and procedural law should aim to achieve appropriate outcomes in a particular case, seeking to satisfy similar meta-interests such as justice, truth, fairness and proportionality, ${ }^{11}$ although some US scholars have argued that they in fact do not achieve this. ${ }^{12}$

Whereas in a simple negligence claim it may plausibly (albeit, it is submitted, incorrectly) be argued that procedural steps do not impact on the same interests as the substantive law, ${ }^{13}$ in a defamation claim procedure and substance both play an important role in

\footnotetext{
9 See further Louis Kaplow, Multistage Adjudication (2013) 126 Harvard Law Review 1179 in particular 12291235.

${ }^{10}$ See Thomas O Main, 'The Procedural Foundation of Substantive Law' (2010) 87 Washington University Law Review 801, 818-822.
}

${ }^{11}$ Adrian Zuckerman, Zuckerman on Civil Procedure: Principles of Practice ( $2^{\text {nd }}$ edn Thomson Sweet \& Maxwell, 2006) ch1 and particularly [1.15-1.16]; Allen Erbsen, 'Substance, Procedure and the Interdependence of Gatekeeping Standards across Multiple Stages of Litigation' $\left(20^{\text {th }}\right.$ November 2013) JOTWELL: Courts Law available at <http://courtslaw.jotwell.com/substance-procedure-and-the-interdependence-of-gatekeepingstandards-across-multiple-stages-of-litigation/>.

12 See e.g. Irwin A. Horowitz \& Kenneth S. Bordens, 'An Experimental Investigation of Procedural Issues in Complex Tort Trials' (1990) 14 Law and Human Behaviour 269, 271; Samuel Issacharoff \& George Loewenstein, 'Second Thoughts About Summary Judgment' (1990) 100 Yale Law Journal 73,75.

${ }^{13}$ However, the development of duty of care as a control mechanism in negligence is partially attributable to the procedural advantages of strike out when examining the existence of duty a question of law compared to the expense of full trial necessary to determine whether a defendant has fallen below the standard of care expected as a question of fact (see Donal Nolan, 'Deconstructing the duty of care' (2013) 129 Law Quarterly Review 559, 568). 
balancing the rights of the parties. The rights most clearly implicated are the rights to freedom of expression and reputation. Whilst clearly ECHR article 6 considerations, which involve the consideration of the claimant's and defendant's right to have their cases dealt with fairly by the court and the courts' interest in the efficient, proportionate and cost-sensitive disposal of claims, ${ }^{14}$ are important in procedural control in actions of all types, and are considered in detail by academics. ${ }^{15}$ This article does not attempt to consider whether the procedural steps utilised by courts in defamation cases are compliant with article 6 , but instead attempts to examine how the interests of the parties and the court shape the important procedural steps that structure a defamation action.

In a defamation action, it is often the procedural manoeuvrings that play a central role in shaping the case, limiting the issues between the parties and shaping a settlement or the result at trial or earlier in proceedings. Therefore, it is necessary to consider the evolutionary development of the procedural steps in defamation cases, particularly in the fields of strike out and summary judgment, to illustrate the steps to achieve a balance between public and private interests.

\section{$\underline{2}$ - The Development of Procedural Control in Defamation Actions}

The majority of defamation claims do not proceed to trial. Some are settled, some cannot be served out of the jurisdiction and some are disposed of through pre-trial applications, such as determinations of meaning, applications for summary judgement or applications to strike out. Both claimants and defendants may benefit from the determination of pre-trial applications, with claimants striking out defences or obtaining summary judgment of their claim, or defendants striking out claim forms and/or particulars of claim on the basis that they fail to comply with procedural requirements or

\footnotetext{
14 This interest can be seen in CPRs rule 1.

${ }^{15}$ See e.g. Joseph M. Jacob, Civil Justice in the Age of Human Rights (Ashgate, 2007);
} 
that they amount to an abuse of process. These disposals are relatively quick and relatively cheap, with no need for the court to engage in detailed examination of evidence. Trials, on the other hand, are generally lengthy and expensive.

These procedural steps allow the courts to control their docket, and to ensure that the limited resources of the Queen's Bench Division, ${ }^{16}$ where defamation cases are usually assigned, ${ }^{17}$ are devoted to a manageable number of cases. Without procedural control it would be impossible to hear all the defamation cases issued within a reasonable period, at reasonable cost. The public interest in proportionate and cost sensitive adjudication therefore requires that pre-trial procedural methods are put in place to enable courts to manage their workload.

The landscape of procedural control has been altered by the introduction of the Human Rights Act 1998. Defamation is an important arena where rights to expression and to private and family life (including reputation) are balanced against each other. ${ }^{18}$ The court must comply with the requirements of the ECHR by virtue of section 6 of the Human Rights Act 1998. Human rights considerations must be taken into account when making procedural judgements, as well as the interest in efficient adjudication. Article 10 of the ECHR provides that 'everyone has the right to freedom of expression.' This 'constitutes one of the essential foundations of a democratic society. ${ }^{19}$ Expression can be restricted on the basis of damage to reputation, but such restrictions must be necessary and

\footnotetext{
${ }^{16}$ Most Defamation cases are dealt with specialist judges, as will be seen in this article, as most of the first instance judgments emanate from Eady J or Tugendhat J, the previous and current Judges in charge of the Queen's Bench Jury and Non-Jury list.

${ }^{17}$ See CPRs Practice Direction 29 paragraph 2.6.

${ }^{18}$ See Stijn Smet, 'Freedom of Expression and the Right to Reputation: Human Rights in Conflict' (2010) 26(1) American University International Law Review 184.

19 Lingens v Austria (1986) 8 EHRR 407, [41].
} 
proportionate. $^{20}$ Defamation claims, even if unsuccessful, can amount to a disproportionate infringement on expression. ${ }^{21}$

Article 8 provides protection for the private and family life, but does not explicitly reference a right to reputation. ${ }^{22}$ However, in Pfeifer $v$ Austria the European Court of Human Rights acknowledged that reputation fell with article 8, stating 'a person's right to protection of his or her reputation is encompassed by Article 8 as being part of the right to respect for private life. ${ }^{23}$ Whilst later cases have sought to limit the scope of the protection of reputation as an independent right, ${ }^{24}$ it is clear that one must engage in consideration of the balance between expression and reputation when assessing whether defamation action imposes an undue burden on the right to free expression. ${ }^{25}$ Further, the importance of reputation has also been acknowledged at common $\operatorname{law}^{26}$ and by

\footnotetext{
${ }^{20}$ Article $10(2)$

${ }^{21}$ See Lonzim v Sprague [2009] EWHC 2838 (QB), [33]. This chilling effect was one of the policy drivers behind the Defamation Act 2013 (see Lord McNally, 'Speech to the Westminster Policy Forum on Reform to the Law of Defamation' (15 ${ }^{\text {th }}$ March 2012) available at <www.gov.uk/government/speeches/westminster-legalpolicy-forum-reform-of-the-law-of-defamation> .

${ }^{22}$ See, in contrast, ICCPR article 17 which provides '[n]o one shall be subjected... to unlawful attacks on his... reputation.'

${ }^{23}$ Pfeifer v Austria (2009) 48 EHRR 8, [35]. See also Axel Springer AG v Germany (2012) 55 EHRR 6, [83]. That the right to reputation is protected by article 8 was acknowledged by the Supreme Court in In $R e$ Guardian News and Media [2010] 2 AC 697, [37]-[42].

${ }^{24}$ See Karakó v Hungary [2009] ECHR 712, Polanco Torres v Spain [2010] ECHR 1341 and Axel Springer AG v Germany which appear to require that an attack on reputation gravely and directly impacts on the personal integrity of an individual before a failure by a state to prevent the attack is seen as a breach of article 8 (see Polanco Torres [40] and Axel Springer [83]).

25 Not least because article 10(2) allows States to, as far as 'necessary in a democratic society,' impose 'restrictions' on the exercise of article 10 rights in order to ensure 'the protection of the reputation... of others.' ${ }^{26}$ See Reynolds v Times Newspapers [2001] 1 AC 127, 201 (Lord Nicholls) and 238 (Lord Hobhouse).
} 
academics. ${ }^{27}$ Some commentators have suggested that the balance between expression and reputation has been incorrectly reached in the law of defamation, arguing in particular that reputational rights have been given insufficient weight. ${ }^{28}$ Until recently courts had been reluctant to strike-out a case which disclosed a good cause of action. Claims were managed through the summary judgment process, with claimants and defendants applying for judgment in cases where the claim was not made out, or a defence could not be answered. As noted below, summary judgement was often refused in defamation cases because of the special function of juries as primary finders of fact in these cases. After examining the summary judgment process, we turn to 'strike out' procedure, and consider how the courts have utilised this procedure to balance competing interests, public and private and reputational and expressive, in a growing number of cases.

\section{Procedural Control of Content: Summary Judgement}

A key way that defamation cases can be managed is through the use of summary procedures found either in Part 24 of the 'CPRs' or the Defamation Act 1996 section 8. These procedures provide twin methods for early adjudication in defamation claims.

\section{Control through Part 24}

Part 24 provides a mechanism by which a court can 'decide a claim or a particular issue without a trial. ${ }^{29}$ Summary judgement requires detailed engagement with the facts of a

27 Robert C Post 'The Social Foundations of Defamation Law: Reputation and the Constitution' (1986) 74 California Law Review 691, who argues that reputation is an important aspect of property, dignity and honour. See also L McNamara, Reputation and Defamation (Oxford University Press, 2007) and David Rolph, Reputation, Celebrity and Defamation Law (Ashgate, 2008).

${ }^{28}$ See e.g. Alastair Mullis and Andrew Scott, 'Worth the Candle: The Government's Draft Defamation Bill' (2011) 3(1) Journal of Media Law 1; Mullis and Scott, above n1.

${ }^{29}$ CPRs rule 24.1 . 
case (set out in the statements of case and accompanying witness statements), assessing whether these show a reasonable prospect of succeeding in the action. However, an application for summary judgement is often accompanied by an application by a defendant to strike out a statement of case under rule $3.4(a) \cdot{ }^{30}$ This examines whether any cause of action is disclosed by the statement of case. The courts tend to determine such two pronged applications on the basis of Part $24 .^{31}$

A claimant can obtain summary judgment where the defendant has 'no real prospect of successfully defending the claim or issue' and there is no other compelling reason for the case to continue to trial. ${ }^{32}$ A defendant can obtain summary judgment where a claimant 'has no real prospect of succeeding on the claim or issue' and there is no other compelling reason for the case to continue to trial. ${ }^{33}$ A successful summary judgement application by a defendant in a defamation case will focus on a defence, and argue that it is bound to succeed, such as where there is an undoubted occasion of qualified privilege with no sustainable argument of malice, ${ }^{34}$ or fail, where a pleaded Reynolds defence is bound to fail because the journalism was not responsible. ${ }^{35} \mathrm{~A}$ defendant may

${ }^{30}$ See Gatley on Libel and Slander, above n8, para 32.34. Summary judgement and strike out can work together in another way, with summary judgement applied for in respect of part of a claim, with the remaining rump challenged as not demonstrating a 'real and substantial' tort (see McKeown v Attheraces Ltd [2011] EWHC $179(Q B))$.

${ }^{31}$ See e.g. Sharma $v$ Jay [2003] EWHC 1230 (QB).

${ }^{32}$ CPRs rule 24.2.

${ }^{33}$ Ibid.

${ }^{34}$ See e.g. Crossland v Wilkinson Hardware Stores [2005] EWHC 481 (QB).

35 See e.g. McKeith v News Group Newspapers [2005] EMLR 32, although note this was decided before the decisions in Jameel $v$ Wall Street Journal and Flood $v$ Times Newspapers, which encouraged the courts to be more expansive in their reading of Reynolds. The Reynolds defence has been abolished and replaced by the statutory defence in Defamation Act 2013 section 4. 
also seek to challenge matters such as publication ${ }^{36}$ or defamatory meaning (although this may require a separate application to determine meaning). ${ }^{37}$

Summary judgement will not be granted where the issue upon which summary judgment is sought is evidentially complex. ${ }^{38}$ In particular courts will not seek at this stage to resolve conflicts of evidence and will not engage in cross-examination. In defamation actions, prior to the changes wrought by the Defamation Act $2013{ }^{39}$ the default factfinder in a defamation action has been a jury, and in Alexander $v$ Arts Council of Wales the Court of Appeal held that where there was an issue fit to be left to the jury, the court should not pre-empt their factual determination on a summary judgment application. ${ }^{40}$ Therefore, a claimant is unlikely to be successful in obtaining summary judgment if there is a dispute surrounding the truth of the statement and a defendant is unlikely to be successful if there is a dispute surrounding meaning. ${ }^{41}$ Whilst trials will now be conducted without a jury, ${ }^{42}$ this is unlikely to substantially increase the circumstances where summary judgement is given, as factually complex matters will not generally be considered appropriate situations for summary judgment.

Summary judgement functions to support existing legal doctrines which balance expression and reputation, where countervailing policy factors have previously been

\footnotetext{
${ }^{36}$ E.g. Wallis $v$ Valentine [2003] EMLR 8.

37 CPRs Practice Direction 53 paragraph 4(1).

38 See Swain v Hillman [2001] 1 All ER 91, 94-95 and Three Rivers DC v Bank of England (No 3) [2003] 2 AC 1, HL, [95] per Lord Hope 'more complex cases are unlikely to be capable of being resolved in that way without conducting a mini-trial on the documents without discovery and without oral evidence... that is not the object of the rule.' In the defamation context see Bataille $v$ Newland [2002] EWHC 1692 (QB).

39 Defamation Act 2013 section 11 renders the default position that trials be conducted by judge alone unless the court orders otherwise.

40 [2001] WLR 1840.

${ }^{41}$ For an example of an application to determine meaning see McAlpine v Bercow [2013] EWHC 1342 (QB).

42 Defamation Act 2013 section 11.
} 
balanced by Parliament or the judiciary. For example, where speech is protected by absolute privilege summary judgement will be granted. ${ }^{43}$ This reflects the pre-existing policy decision that the value of speech is such that it should not be restricted by countervailing concerns. ${ }^{44}$ Summary judgement procedures themselves do not focus on the balance between rights, but enable doctrines that operationalize this balance to be applied at an early stage.

Of course, one area where rights may be considered is in the examination of whether there is another compelling reason to proceed to trial in cases where a reasonable prospect of success cannot be demonstrated. Although there is little case law in the area, procedural rights, such as the right to trial by jury, may be advanced as a compelling reason to refuse summary judgement and continue a claim to trial. However, the claimant's article 6 rights alone do not mean that there is always a compelling reason for the case to continue to trial. One cannot argue that a case must go to trial because that would vindicate rights under article 6 . There must be something more compelling that provides a reason for a case to go to trial.

\section{Defamation Act 1996}

The Defamation Act 1996 contains a specific summary disposal mechanism. ${ }^{45}$ Section 8 provides that a court may summarily dispose of a claim if, on application by the defendant, 'it appears to the court that it has no realistic prospect of success and there is no reason why it should be tried ${ }^{\prime 46}$ or if, on application by the claimant, 'it appears to the court that there is no defence to the claim which has a realistic prospect of success,

\footnotetext{
${ }^{43}$ See e.g. White $v$ Southampton University NHS Hospitals Trust [2011] EWHC 825 (QB).

${ }^{44}$ For a review of the policy considerations see Westcott $v$ Westcott [2009] QB 407.

45 This statutory intervention was necessary because the old Rules of the Supreme Court Order 14 expressly excluded defamation cases from its scope.

${ }^{46}$ Defamation Act 1996 section 8(2).
} 
and that there is no other reason why the claim should be tried. ${ }^{47}$ The test of realistic prospect of success is the same as that under the CPRs, ${ }^{48}$ and in determining whether 'other reason[s]' are present the court should consider the factors listed in section 8(4), which broadly reflect those under Part 24. However, the summary procedure under the Defamation Act is more limited than that under the CPR. Applications must be made in respect of the whole of a claim, ${ }^{49}$ whereas summary judgement under Part 24 can be made in respect of part of a claim. ${ }^{50}$ Further, the procedure under the Act is only open to claimants who seek less than $£ 10,000 .^{51}$

\section{Summary}

By focusing on the prospects of success, summary judgement enables courts to swiftly remove cases which are likely to fail. This supports the pre-existing statutory and common law mechanisms which seek to balance expression and reputation, removing cases where the potential returns do not justify the resources expended. Well advised claimants or defendants may choose to discontinue, settle or not an issue in situations where there is a risk of summary judgment, reducing the burden on expression.

However, summary judgement does not attempt to reach independent judgements about the balance that should be struck in a particular case, focusing instead on the satisfaction, or otherwise, of external requirements for a successful claim or defence. If the court wishes to procedurally control a claim on the basis of the impingement on

\footnotetext{
47 Defamation Act 1996 section 8(3).

${ }^{48}$ Downtex v Flatley [2003] EWCA Civ 1282.

${ }^{49}$ As is required by Defamation Act 1996 section 8.

${ }^{50}$ See CPRs part 24.1. Under Part 24 a defendant may apply in respect of some, but not all, statements.

${ }^{51}$ Summary judgement under section 8 is only available where summary relief (defined in section 9) is sufficient to 'adequately compensate' the claimant (s8(3)).
} 
expressive rights in circumstances where the claimant has a reasonable prospect of a successful claim, then the court must act to strike out the claim.

\section{Procedural Control of Conduct: Strike-out}

The power to strike out

The court's power to strike out is contained in Rule 3 of the CPRs. Rule 3.4(2)(a) allows a court to strike out where a statement of case 'discloses no reasonable grounds for bringing or defending the claim.' This power requires the court to assess the statement of case that is the subject of the application. The power in Rule 3.4(2)(a) is similar to the power to grant summary judgement in Part $24 .^{52}$

More importantly, Rule 3.4(2)(b) allows courts to manage claims where the existence of a cause of action on the pleadings is undisputed. The court can strike out 'if it appears to the court... (b) that the statement of case is an abuse of the court's process or is otherwise likely to obstruct the just disposal of the proceedings.' The contents of a statement of case will be assessed to determine whether it is an abuse of the courts process, ${ }^{53}$ and it will be an abuse if a claimant or defendant is using the 'process for a purpose or in a way significantly different from its ordinary and proper use. ${ }^{154}$ The courts have identified a number of situations where they are willing to strike out a statement of case as an abuse, including vexatious litigation, litigation which seeks to re-litigate decided issues or which stages collateral attacks on previous judgements, ${ }^{55}$ litigation for

\footnotetext{
52 Indeed, applications to strike out under rule 3.4(a) are often made in combination with an application for summary judgement under rule 24 (see Gatley on Libel and Slander (n8) [32.24]).

${ }^{53}$ Abuse of process may amount to a tort (see Land Securities Plc v Fladgate Fielder [2010] Ch 467, which strictly limits its scope), but consideration of this is outside the scope of this piece.

${ }^{54}$ Attorney General v Barker [2000] 1 FLR 759, DC, [19] per Lord Bingham C].

55 Johnson $v$ Gore Wood [2002] 2 AC 1, HL. In the defamation context, using a claim to collaterally attack a criminal conviction will lead to a claim being struck out (Krause v Newsquest Media Group [2013] EWHC 3400
} 
an improper collateral purpose, ${ }^{56}$ litigation which is improperly delayed, ${ }^{57}$ litigation which is conducted fraudulently ${ }^{58}$ and litigation which is pointless and wasteful. The last of these has assumed great importance in the control of defamation claims, and in achieving the balance between rights to reputation and expression.

Rule 3.4(2)(b) must be contrasted with the further power in rule 3.4(2)(c) to strike out where 'there has been a failure to comply with a rule, practice direction or court order. ${ }^{59}$ This power to strike out is based on the conduct of a claim, rather than the contents of the claim itself. ${ }^{60}$ However, when deciding whether a breach justifies an exercise of the discretion to strike out the court must take into account all the circumstances of the claim, which may require an assessment of the balance between public and private interests. ${ }^{61}$ If the conduct of a claim amounts to an abuse of process the strike out should be grounded in paragraph (c) rather than paragraph (b). ${ }^{62}$

(QB) [21]). This was previously a legitimate tactic, and prior to 1907 was the only way to challenge a criminal trial courts determination (see Matthew Dyson, 'Civil Law Responses to Criminal Law Judgments in England and Spain' (2012) 3 Journal of European Tort Law 308, 320-322).

56 The law relating to abuse on the basis of improper collateral purpose is summarised by Teare $\mathrm{J}$ in JSC BTA Bank v Ablyazov (No 6) [2011] 1 WLR 2996, [22].

${ }^{57}$ Habib Bank v Jaffer [2000] CPLR. 438, CA.

58 Summers v Fairclough Homes [2012] UKSC 26; [2012] 1 WLR 2004.

${ }^{59}$ CPRs rule 3.4(c).

60 This contrast is noted in the White Book commentary to rule 3.4. For an example of strike out on this basis in a defamation context see Hayden $v$ Charlton [2010] EWHC 3144 (QB).

${ }^{61}$ CPRs rule $1(2)(c)$.

62 See contra Adelson $v$ Anderson [2011] EWHC 2497 (QB). A better reading of the case is that events subsequent to the issue of the claim had meant that, at the time of the application, there was no 'real and substantial' tort, although there may have been at the point of issue (see Morrissey $v$ McNicholas [2011] EWHC $2738(\mathrm{QB}))$ 
An application to strike out may be made by the parties, or by the court of its own volition. ${ }^{63}$ The power exists even where the exercise of the power would 'defeat a substantive claim. ${ }^{64}$ Even if the claimant can demonstrate a published statement from which it is possible to identify defamatory allegations, and there are no applicable defences, a claim may still be struck out as an abuse. This would deprive an individual of their right to the determination of the underlying claim, and therefore the 'draconian step of striking a claim out is always a last resort. ${ }^{65}$

The court possesses this power in order to do justice between the parties or to prevent the bringing of the 'administration of justice into disrepute among right-thinking people. ${ }^{166}$ Where other case management steps can be taken to manage the progress of the case, and ensure that it not an abuse, these will be preferred to strike out, ${ }^{67}$ although strike out will remain available if they fail. Recent changes to the CPRs that may assist the court in managing a case and avoiding strike out by, in particular, enhancing the court's ability to manage costs, are outlined in part 4 of this article.

\section{Strike out in defamation cases}

The principal decision striking out a claim as an abuse of process in defamation is that of the Court of Appeal in Jameel $v$ Dow Jones. ${ }^{68}$ The Court struck out particulars of claim

\footnotetext{
${ }^{63}$ CPRs rule 3.3.

${ }^{64}$ Summers $v$ Fairclough Homes, above n58, [41].

${ }^{65}$ Summers $v$ Fairclough Homes, above n58, [49].

${ }^{66}$ Hunter v Chief Constable of the West Midlands Police [1982] AC 529, 536 per Lord Diplock, approved postCPRs by the Supreme Court in Summers v Fairclough Homes, above n58, [34]-[35].

67 In Ansari v Knowles [2013] EWCA Civ 1448, [23], the Court of Appeal refused to strike out a claim and instead preferred a 'firm exercise of the court's case management powers.'

${ }^{68}$ [2005] QB 946. Jameel can apply to other torts which focus on the balance between article 8 and article 10 (see Price $v$ Powell [2012] EWHC 3527 (QB) (misuse of private information); Austen $v$ University of
} 
where the pleaded publication was so miniscule that the harm done by the publication was disproportionately small compared to the costs that would be expended on proceedings, notwithstanding the defamatory meaning of the statement. ${ }^{69}$ The 'game was not worth the candle,' and was, in fact, barely 'worth the wick. ${ }^{70}$ The court must 'approach the matter... on the assumption that [the claimant] will succeed at the end of the day and ask... whether [the claimant] should be prevented from pursuing his claim because the costs will be out of all proportion to the benefit he is likely to obtain. ${ }^{71}$ Prior to Jameel cases with limited publication would go to trial, and the limited harm would be relevant to the remedy, rather than as a consideration in case management decisions. There had been previous decisions which had struck out wasteful cases, ${ }^{72}$ but these were isolated instances. In general, only in cases where an application was made to serve out of the jurisdiction under CPRs rule 6.36(6) (or its antecedents CPR rule 6.20(8) and RSC order 11) did the courts consider whether the pleadings disclosed a substantial tort within the jurisdiction. ${ }^{73}$ According to Tugendhat J, post-Jameel 'It is the duty of the court to bring to an end proceedings that are not serving the legitimate purpose of defamation proceedings. ${ }^{17}$

Wolverhampton [2005] EWHC 1635 (QB) (Data Protection Act 1998)). However, it should be confined to such torts (see contra Lilley v Chartered Institute of Management Accountants [2013] EWHC 1354 (Ch)).

${ }^{69}$ According to the Court of Appeal in Tesla Motors Ltd v BBC [2013] EWCA Civ 152, [48] Jameel, above n6, is aimed at 'proceedings which, although technically well-founded, [are] unlikely to serve any useful purpose.'

70 Jameel, above n6.

${ }^{71}$ Ansari $v$ Knowles, above n67, [18].

72 Schellenberg $V$ BBC [2000] EMLR 296, 319, although the primary abuse argument was focused on relitigation of issues determined in previous libel actions.

${ }^{73}$ See Kroch v Rossell et Cie Société des Personnes à Responsibilité Ltd [1937] 1 All ER 725 and Chadha v Dow Jones \& Co Inc [1999] EMLR 724, 732.

${ }^{74}$ Lonzim v Sprague [2009] EWHC 2838 (QB), [34]. 
Jameel was said to rest on twin developments which suggest a greater willingness to strike out. First, there is the post-Woolf Report role of the courts in proactively managing cases before them. ${ }^{75}$ Prior to the reforms embodied in the CPRs the situation in civil justice was that 'expense is often excessive, disproportionate and unpredictable; and delay is frequently unreasonable' because of the lack of 'effective judicial control. ${ }^{176}$ In his final report, Lord Woolf spoke of the creation of a 'new landscape' in which courts were able to deal proportionately with cases brought before them, and where courts, rather than parties were responsible for managing the litigation process. ${ }^{77}$ One of the tools which the courts have to enable cases to be dealt with proportionately is the power to strike out a case as an abuse of process. ${ }^{78}$

The second alteration to the adjudicative landscape which underpins the decision in Jameel is the implementation of the Human Rights Act. The rights to expression and reputation discussed above ${ }^{79}$ must therefore be balanced against one another.

When considering how to balance these competing right in defamation cases, Lord Phillips held in Jameel that 'keeping a proper balance between the article 10 right of freedom of expression and the protection of individual reputation must, so it seems to us, require the court to bring to a stop as an abuse of process defamation proceedings that are not serving the legitimate purpose of protecting the claimant's reputation.' Further, Laws $\mathrm{LJ}$ has conceptualised the balancing aspect of the decision in Jameel as

\footnotetext{
${ }^{75}$ See CPRs rule $1(1)$, which provides that the courts should 'deal with cases justly and at proportionate cost.'

${ }^{76}$ Lord Woolf, Access to Justice: Interim Report to the Lord Chancellor on the Civil Justice System in England and Wales (HMSO, 1995) Chapter 3 paragraph 4.

77 See Lord Woolf, Access to Justice: Final Report to the Lord Chancellor on the Civil Justice System in England and Wales (HMSO, 1995) Overview paragraphs 8-9.

${ }^{78}$ In early cases following the implementation of the CPRs great stress was laid upon managing cases so that 'real issues' could be dealt with proportionately and other issues excluded (see McPhilemy $v$ Times Newspapers [1999] 3 All ER 775, 791).

${ }^{79}$ See text to note $18 f f$.
} 
constitutionally required; 'the balance to be struck between public interest and private right is increasingly to be seen as a function of our constitution... It is no more than an ordinary incident of the common law's incremental method that familiar notions such as abuse of process should be fashioned for its service. ${ }^{80}$

Cases which have limited value are therefore removed from the court system as soon as possible, in order that scarce court resources are devoted to cases of greater import. Adrian Zuckerman has argued, as long ago as 1975, for the importance of 'procedural proportionality' which requires that a case is 'sufficiently substantial to justify use of normal processes' in order to remain within the normal adjudicative process. ${ }^{81}$ Indeed, procedural proportionality has been expressly acknowledged as a goal of Jameel. ${ }^{82}$ This has been criticised as weighing pragmatic aims of cost reduction more heavily than adjudicative accuracy. ${ }^{83}$ Indeed, as noted above, decisions to strike out for an abuse of process will result in a claimant who has suffered a legal wrong being left uncompensated. However, assessment of procedural proportionality in defamation cases may be viewed as principled, because of the importance accorded to defendants' rights to free expression. These may be burdened by the progress of litigation (even if eventually it is successfully defended). This leads to a closer engagement with an assessment of procedural proportionality in the defamation cases post-Jameel, with a balancing of possible beneficial outcomes for the claimant against the costs (both monetary and to speech) in continuing with the case. Only where the reputation

${ }^{80}$ Lait v Evening Standard Ltd [2011] 1 WLR 2973, [45].

${ }^{81}$ A. A. S. Zuckerman, 'A Reform of Civil Procedure--Rationing Procedure rather than Access to Justice' (1975) 22 Journal of Law and Society 155.

${ }^{82}$ In Sullivan v Bristol Film Studios [2012] EWCA 570 Lewison L] stated that the goal of Jameel is to establish 'whether in any particular case there is a proportionate procedure by which the merits of a claim can be investigated.'

${ }^{83}$ Derek O'Brien, 'The new summary judgement: raising the threshold of admission' (1999) 18 Civil Justice Quarterly 132 
interests are 'sufficiently substantial' will the use of court resources be seen as worthwhile.

A further reason for the development of strike-out as a method of control in defamation actions, discussed by Lord Phillips in Jameel, ${ }^{84}$ is the inflexibility of case management powers in defamation when compared to other claims. In most cases the courts are able to assign a case to one of three procedural tracks, ${ }^{85}$ the small-claims track, the fasttrack and the multi-track. The most complex cases are assigned to the multi-track, and such cases involve the most detailed and expensive procedural steps. A court must invariably assign a defamation claim to the multi-track, ${ }^{86}$ and even where the value of the claim is low cannot assign a defamation claim to the small-claims track, whereas other non-personal injury cases with a value of less than $£ 10000$ will be assigned to that track. ${ }^{87}$ All defamation claims must be dealt with in the specialist list at the Royal Courts of Justice, a process which is lengthy, expensive and adversarial. Therefore a strike-out provides the only possible route to manage cases that have limited value, and which have the potential to utilise extensive resource.

As noted above the use of the strike-out power deprives claimants of the opportunity to have their claims determined by a court, and in defamation in particular this deprives the

\footnotetext{
${ }^{84}$ Jameel, above $n 6,[70]$ which notes that '[n]ormally where a small claim is brought, it will be dealt with by a proportionate small claims procedure. Such a course is not available in an action for defamation where, although the claim is small, the issues are complex and subject to special procedure under the [CPRs].'

85 See CPRs Parts 26-29. Part 26 deals with allocation to track, and Parts 27-29 outline the procedures applicable to each track.

${ }^{86}$ Derek O'Brien, 'The new summary judgement: raising the threshold of admission' (1999) 18 Civil Justice Quarterly 132, 148 argues that 'tracking' introduced by the CPRs should be seen as an alternative to strike out and summary judgement as it already allows allocation of resources to particular cases in proportion to the matters at issue in the case.

${ }^{87}$ CPRs rule 26.6(3).
} 
claimant of the opportunity for a jury trial. This feature of the strike out power initially caused courts to be somewhat reticent in its use. In Jameel itself an argument was advanced that an order to strike-out the claim was incompatible with article 6 of the European Convention on Human Rights. Lord Phillips rejected this argument, holding that article 6 does not require a full trial where a claim is neither real nor substantial. ${ }^{88}$ In such a case, the hearing of the strike out application provides a fair and public hearing necessary to determine the rights of the claimant, as he or she does not have a right to damages in such a case. Similarly, Lord Neuberger MR has held that cases where there is no substantial tort provide an appropriate exception to the general rule that 'so long as [a claimant] has an arguable claim she should be allowed to proceed with $\mathrm{it}^{\prime} .{ }^{89}$ Indeed, where there is no substantial tort, it is unlikely that article 8 is engaged, as the decision of the European Court of Human Rights in Polanco Torres requires that the damage to reputation must be grave and direct. ${ }^{90}$ However, given the importance of the interests at stake, the court must engage in a detailed balancing exercise before deciding to strike out. It is this balancing that renders the procedure compatible with articles 6 and 8 . It is to this examination that we now turn.

\section{Determining whether a claim should be struck out as an abuse of process}

The primary test advanced to determine whether the claim should be struck out is whether the pleadings show a 'real and substantial' tort. ${ }^{91}$ This should be judged at the

\footnotetext{
88 Jameel, above n6, [71]. For similar statements see Gustafson v Sweden (1998) 25 EHRR 623, [38], using 'genuine and serious' as the threshold.

${ }^{89}$ Lait v Evening Standard, above n80, [57] per Lord Neuberger MR

90 Polanco Torres, above n24, [40]

${ }^{91}$ This is function of the judge 'with which [the Court of Appeal] should not interfere unless satisfied that he was wrong' (Lait v Evening Standard, above n80, [63] per Lord Neuberger MR).
} 
date of the hearing of the application to strike out. ${ }^{92}$ However, given the competing interests in play, it is essential that the court conducts a case specific balancing exercise on the basis of the claimant's pleaded case. It is clear that 'it is not appropriate for the court to undertake any kind of mini-trial, based upon incomplete evidence, either as to liability or quantum' when considering an application to strike out. ${ }^{93}$

As noted by Zuckerman, 'if the court were to strike out a claim for minor infractions it would go beyond what was necessary to protect its process and may itself become a source of injustice. ${ }^{\prime 94}$ Indeed, 'the court must exercise particular care before shutting out an arguable case. ${ }^{95}$ As noted by Dingemans $\mathrm{J}$ in Subotic $v$ Knezevic, 'applications to dismiss proceedings as an abuse of process must not become a routine, expensive, procedural hurdle over which claimants are forced to jump in an attempt to secure justice. ${ }^{96}$ Concern about the potential for Jameel applications to impede the ability of claimants to vindicate their reputation is tacitly expressed in this passage from the judgment of Dingemans $\mathrm{J}$ in Subotic. To prevent this injustice the burden is on the person seeking to strike out (in Jameel type cases the defendant) to establish that the pleadings do not disclose a real and substantial tort. ${ }^{97}$ It is, however, clear that the approach of the court should not be that 'these claims look very thin to me, but it is

${ }^{92}$ Adelson $v$ Anderson [69] per Tugendhat $\mathrm{J}$ 'in my judgment what is now at stake in this action does not justify the deployment of [court] resources' (authors emphasis).

${ }^{93}$ Ansari v Knowles, above n67, [27] per Vos LJ.

${ }^{94}$ Adrian Zuckerman, 'Court protection from abuse of process - the means are there but not the will' (2012) 31 Civil Justice Quarterly 377.

${ }^{95}$ Lait $v$ Evening Standard, above n80, [57] per Lord Neuberger MR

${ }^{96}$ Subotic v Knezevic [2013] EWHC 3011 (QB) [63].

97 See the comments on burden of proof in Dexter $v$ Vlieland-Boddy [2003] EWCA Civ 14, [49] per Clarke LJ. Although this is a case concerned with strike out on the basis of an attempt to re-litigate decided issues it is submitted that these conclusions should be applied generally to applications to strike out as abuse of process. 
safer not to strike them out until there has been some (expensive) evidence. ${ }^{198}$ The court should be pro-active in ensuring that claims which amount to an abuse of process 'are weeded out at the earliest possible stage. ${ }^{199}$

When applying Jameel to the facts of a case in front of it, the courts have vacillated on the factors to be taken into account when considering whether a tort is 'real and substantial.' The courts have focused either on the possibility of vindication through the claim or the pleaded remedies. It is submitted that the former is the better approach. The rule in Jameel must 'not... be categorised merely as a variety of the de minimis rule tailored for defamation actions ${ }^{\prime 100}$ and therefore one must not simply examine the claimed damages when determining whether the tort is real and substantial. Determining whether the tort is real and substantial is more complex.

Mere limited publication cannot, on its own, lead to a case being struck out as an abuse of process. ${ }^{101}$ However, the extent of publication is an important consideration. In Jameel itself the publication had been read by five subscribers to the Wall Street Journal website, three of whom were members of the 'claimant's camp. ${ }^{102}$ The small number of publishees was taken into account in determining that there was no real and substantial tort. ${ }^{103}$ In contrast, in Mama Group $v$ Sinclair the 'very extensive publication' was a reason to refuse an application to strike out ${ }^{104}$. As well as the number of publishees, it is clear from Mama that their identity as 'licensors, commercial partners and customers' is

\footnotetext{
${ }^{98}$ Dowson v Chief Constable of Northumbria [2009] EWHC 907 (QB), [58] per Coulson J.

99 Ibid.

100 Lait v Evening Standard, above n80, [42].

${ }^{101}$ Al Baho v Ali Meerza [2011] EWHC 2984 (QB), [5].

102 Jameel, above n6, [17].

103 Jameel, above n6, [71].

104 Mama Group v Sinclair [2013] EWHC 2374 (QB), [49]
} 
also a relevant consideration. ${ }^{105}$ Conversely, where the opinion of the publishees is unlikely to be influenced by the publication this may be a relevant factor in concluding that the case is an abuse. ${ }^{106}$ Limited publication should be weighed against the substance of the allegations. The more serious the defamatory allegation, the more likely it is that the claim will not be struck out on the grounds of the limited publication.

The balance will favour strike out where the claim cannot function to vindicate the claimant's reputation. ${ }^{107}$ In Krause $v$ Newsquest Media Group Ltd the claimant issued proceedings in respect of an article reporting a successful appeal against sentence following a conviction for harassment. The claim was struck out because 'having regard to the damage to her reputation that she suffered by reason of the convictions... there is nothing of any possible benefit to her which she can achieve' in the defamation action. ${ }^{108}$ Here the vindication is not worth the resources to be expended by the court, taking into account the public interest in reporting about the claimant, whose sentence had been reduced following a conviction for harassment. Similarly, in Williams $v$ MGN the court held that a claim that sought the vindication of the reputation of a convicted murderer was not 'worth the wick. ${ }^{109}$ However, it is possible to read this case as an example of

105 Mama Group v Sinclair, ibid., [34].

${ }^{106}$ See Crossland $v$ Wilkinson Hardware Stores, above n34, [87]-[97]. Similarly, the criticism advanced by the Court of Appeal in Jameel, above n6, of Duke of Brunswick v Harmer (1849) 14 QB 185 appears partially based on the identity of the publishee, although is also based on the publication to one person only and conduct of the Duke (see Jameel [56]).

107 According to Pena v Tameside Hospital NHS Foundation Trust [2011] EWHC 2984 (QB) access to the courts should only be available where the claim is made with a view to achieving 'genuine vindication.'

108 [2013] EWHC 3400 (QB), [56]. This ground is offered as an alternative, with the statement of claim also struck out because the pleaded words had no defamatory meaning. See similarly Makudi $v$ Triesman [2013] EWHC 142 (QB), where obiter a Jameel application was said to be likely to succeed unless the claim gave the claimant 'a remedy which gave him something of value notwithstanding the damage to that reputation already caused by the extensive publicity that had been generated.'

109 [2009] EWHC 3150 (QB). 
strike out under rule $3.4(2)(a)$, as, given the claimants pre-existing reputation, the alleged defamatory statement could not lower the claimant in the eyes of the reasonable member of the public. It would also be proper to give summary judgement on the claim because the claimant had 'no real prospect' of demonstrating he satisfied the threshold of harm required by Thornton $v$ Telegraph Media Group. ${ }^{110}$

On the other hand, where there is a reputation capable of vindication the courts will be slower to strike out the claim. ${ }^{111}$ In Ansari $v$ Knowles the Court of Appeal refused to strike out a claim that could 'provide vindication in respect of serious allegations' despite limited publication. ${ }^{112}$ If the claim shows a 'real need for vindication' the court will be slow to strike it out. ${ }^{113}$ Even where the claimant's reputation has been vindicated through an apology or retraction, a claim may continue to disclose a real and substantial tort if there is a prospect of obtaining damages. ${ }^{114}$ However, where the claimant can vindicate his reputation, but this would not amount to 'worthwhile vindication,' the claim will be struck out. ${ }^{115}$ A publication pre-dating the issue of the claim which operates to vindicate the claimant's reputation may, when combined with other factors, suggest that the claim should be struck out. ${ }^{116}$

${ }^{110}$ [2011] 1 WLR 1985, [90]-[96]. The possibility of summary judgment in such circumstances is considered in part 3 below.

111 This accords with the approach in Karakó v Hungary, above n24, and Polanco Torres v Spain, above n24, which suggest that the right to reputation will only be engaged where serious harm has been suffered. If no serious harm has been suffered, there is no need for vindication.

${ }^{112}$ Ansari v Knowles, above n67, [19].

${ }^{113}$ Khalil v Barakat [2013] EWHC 85(QB).

${ }^{114}$ Ronaldo $v$ Telegraph Media Group [2010] EWHC 2710 (QB). In this case the defendants have republished a defamatory statement which had later been retracted by the original publishers. An application to strike out on the basis that further vindication was impossible was struck out.

${ }^{115}$ Davison v Habeeb [2011] EWHC 3031 (QB), [27].

${ }^{116}$ Cammish v Hughes [2012] EWCA Civ 1655, [60]. 
In some cases the pleaded remedies may suggest that the case is an abuse. Where the claimant has suffered no damage it is difficult to say that the game is worth the candle. ${ }^{117}$ In Scotland, it has been suggested that the likely level of damages should be a consideration and it would be proper to strike out a claim where an 'action would be disproportionate to its value. ${ }^{118}$ However, '[t]he mere fact that a claim is small should not automatically result in the court refusing to hear it at all, ${ }^{119}$ and where 'it is by no means improbable that the damages would be more than nominal' then the court may refuse to strike out a claim as an abuse of process ${ }^{120} \mathrm{~A}$ blanket approach where cases are struck out as an abuse merely because of the value of the claim would be likely to face serious challenge under article 6 and article 8 of the ECHR. Where an injunction is sought to prevent future publication, this may tend to suggest that a claim is not an abuse, provided that the injunction can serve the purpose of preventing further damage to reputation. ${ }^{121}$

The content of a pleaded defence may also influence the application of Jameel. In Lait $v$ Evening Standard, where a defence of honest comment or Reynolds privilege was advanced, then the importance of freedom of expression could be taken into account when making a determination whether the case disclosed a real and substantial tort, with a pleaded defence founded on expressive rights more likely to render a case an abuse of process. ${ }^{122}$ However, this case considered a claim relating to a statement with

\footnotetext{
117 See Tilbrook v Parr [2012] EWHC 1946 (QB).

${ }^{118}$ Ewing v Times Newspapers 2010 SLT 1093.

${ }^{119}$ Sullivan v Bristol Film Studios, above n82, [29].

${ }^{120}$ Baturina v Times Newspapers Ltd [2011] 1 WLR 1526, [42]. See also Abbey v Gilligan [2012] EWHC 3217 (QB), [182] where it was stated that if the claim had been brought 'by a claimant who might have had a prospect of obtaining substantial damages' then 'it might not have been a case of Jameel abuse.'

${ }^{121}$ See Tesla Motors Ltd $\vee$ BBC, above n69, [49] where an injunction was held to serve no such purpose and Cammish $v$ Hughes, above n116, [60].

122 Lait $v$ Evening Standard, above n80, [42]-[44].
} 
two possible meanings, and is perhaps better read as determining which meaning should be considered for the purpose of the Jameel balancing exercise. Lait holds that the narrower reading should be considered. On the other hand, in Ansari $v$ Knowles it was made clear that the fact that the defendants advanced justification as a defence cannot give a claimant an extra interest in pursuing a claim beyond the interest when the claim was issued. ${ }^{123}$ The pleaded defence cannot make a claim worth the candle where it was not worthwhile independent of the defence.

The overall costs of a trial can be considered. Where these are likely to be large, the claimant must demonstrate that the result of the trial will justify these costs. ${ }^{124}$ However, the court cannot strike out a claim on the basis that a defendant would be unable to recover costs from the claimant if successful. Whilst costs may amount to a burden on freedom expression, ${ }^{125}$ and this burden may be amplified in the event that costs are not recoverable, to take into account financial circumstances would illegitimately disturb the balance of the CPRs, ${ }^{126}$ which provide for security for costs only in limited circumstances. ${ }^{127}$

Drawing these insights together, it is submitted that there are two steps the court must take before for striking out on a Jameel basis. First, the court must decide whether the statement of case demonstrates that the claimant has suffered harm to reputation. Second, the court must consider whether the expenditure of court resources is

${ }^{123}$ Ansari $v$ Knowles, above n67, [20]. Similarly, the conduct of the defendant in responding to a claim should not influence the decision whether the claim discloses a real and substantial tort (see Cammish $v$ Hughes, above n116, [67]).

${ }^{124}$ Cammish $v$ Hughes above n116, [60].

${ }^{125}$ MGN Ltd $v$ UK (2011) 53 EHRR 5 and see in general Kirsty Hughes, 'Balancing rights and the Margin of appreciation: Article 10, Breach of confidence and Success Fees' (2011) 3(1) Journal of Media Law 29.

${ }^{126}$ Ansari v Knowles, above n67, [19].

127 CPRs rule 25.13. 
worthwhile given the damage to reputation alleged (and the vindication that can be achieved), taking into account the right to freedom of expression guaranteed by the European Convention on Human Rights. Where the reputational interest is significant (and the claim may lead to vindication) the court should be willing to let the claim proceed, as this will justify the resource expenditure and will not conflict with the right to freedom of expression.

At the first stage, where the reputation of the individual cannot be vindicated by the defamation action, the claim must be struck out as an abuse of process. At the second stage the considerations set out above must be taken into account. The court must first consider how serious the reputational damage complained of was, examining the breadth of publication and the identity of the persons to whom the allegations had been published. Then consideration must be given to whether success in the case as pleaded is capable of vindicating the reputation damage suffered by the claimant. This will be weighed against the resources that the court will have to bring to bear in determining the claim. Further, the importance of article 10 rights should be considered, bearing in mind that the mere issue of a claim can amount to a burden on the exercise of these rights.

\section{Summary}

The courts have developed procedural tools to allow the management of defamation cases where the continuation of a case would impinge on expressive rights. Where a predetermined balance has been reached through provision of a defence in certain circumstances, the summary judgment procedure provided by CPRs Part 24 will allow the claim to be swiftly determined. Where a good claim on the merits may be advanced by a claimant, a Court may strike out the claim as an abuse of process if the impingement on free speech is too great, taking into account the public and private interests in the continuation of the case. However, this will involve a detailed balancing 
exercise, which should take into account, in particular, the possibility that a successful claim as pleaded will lead to vindication of the claimant's reputation.

\section{3 -Changes to Procedural Control post-Defamation Act 2013}

This section considers the effect of the 2013 changes to the substantive law of defamation on the procedural management of claims. Section 1 of the Defamation Act 2013 imposes a requirement that a claimant demonstrate an additional element in order to be successful.. As well as showing that a published defamatory statement, from which the claimant can be identified, has 'lowered the claimant in the eyes of right thinking members of society' or caused the right-thinking members of society to 'shun or avoid' him, the claimant must also show that the publication of the defamatory statement has caused, or is likely to cause, 'serious harm.' The burden rests on the claimant to both plead and prove with evidence that serious harm has been suffered or is likely. Where the claimant is a corporate body acting for profit the harm must be 'serious financial loss. ${ }^{128}$ It is submitted that the harm demonstrated must be harm within the UK, the EU or states signatory to the Lugano Convention. ${ }^{129}$

It is clear that section 1 raises the threshold of damage that must be suffered by the claimant before a claim can be brought. The explanatory notes to the Act make clear that the requirements under section 1 go beyond the threshold imposed by Thornton $v$ Telegraph Media Group. ${ }^{130}$ However, the meaning of 'serious' harm is unclear. It is submitted that some guidance on the meaning of harm can be found in slander cases, ${ }^{131}$

\footnotetext{
128 Defamation Act 2013 section 1(2).

${ }^{129}$ This is implied by Defamation Act 2013 section 9, and see the judgment in Subotic $v$ Knezevic, above n96.

${ }^{130}$ Above n110, [90]-[96].

${ }^{131}$ As harm must be demonstrated, this must also include a requirement to demonstrate that the defamatory statement caused the harm. It is submitted that the causation requirements should be those adopted in Slander and Malicious Falsehood (see Barrett v Associated Newspapers (1907) 23 TLR 666).
} 
in circumstances where a claim was not actionable per se. ${ }^{132}$ In the slander cases, the claimant was required to demonstrate 'actual temporal loss ${ }^{\prime 133}$ which includes pecuniary losses, ${ }^{134}$ but can also include social losses, such as deprivation of the hospitality of friends. ${ }^{135}$ Using these cases it is clear that publication must result in tangible effects to amount to 'harm' as required by the Act. However, the tangible effects need not be restricted to financial consequences. On the other hand, mere annoyance is unlikely to amount to harm for the purposes of the Act, as the focus should be on the effect on a third party, rather than the effect on the individual. ${ }^{136}$

It may be that the introduction of a 'harm' requirement by section 1 of the Defamation Act 2013 will lead to less reliance on Jameel strike-outs. ${ }^{137}$ This is because the question whether a tort is substantial would become an ingredient of the tort. Just as a negligence pleading must identify damage, so must a post-2013 defamation pleading, but unlike the negligence pleading the damage must reach a threshold of 'serious harm' to reputation, or, in the case of a company, 'serious financial loss.' Rather than issuing an application to strike out particulars on the basis that the pleading is a Jameel abuse of process, an application may be made for strike out under rule $3.4(2)(a)$ arguing that the pleading fails to disclose a tort or for summary judgement under Part 24 on the basis that the

\footnotetext{
132 Those cases which did not fall within the exceptions to the requirement of proving damage at common law (words alleging a crime, words imputing a contagious disease or words calculated to disparage the claimant in relation to trade, office or profession) or Statute (Slander of Women Act 1891 (now repealed by the Defamation Act 2013)).

${ }^{133}$ Ratcliffe $v$ Evans [1892] 2 QB 524, 532.

${ }^{134}$ Such as loss of employment or loss of clients (see Bateman v Lyall (1860) 7 CBNS 638.

135 Moore v Meagher (1807) 127 ER 745.

${ }^{136}$ Weldon v De Bathe (1884) 54 LJQB 113, 116.

137 The inclusion in the explanatory notes of Jameel, above n6, alongside Thornton and Sim v Stretch (1936) 52 TLR 669, HL, as cases which the section 'builds on' adds weight to this suggestion.
} 
claimant has no real prospect of success in demonstrating that 'serious harm' or 'serious financial loss.'

This would shift the issue from the balancing exercise by the court in determining whether the 'game was worth the candle' to asking whether the claimant had a reasonable prospect of satisfying one of the required elements of the claim. This shift in focus could engage the evidential basis of the claimant's contentions at an early stage, requiring an examination of the likelihood of demonstrating (on a balance of probabilities) whether there was a real prospect of demonstrating 'serious harm.' It is likely that such an application would be made under CPR, Part 24 (or rule $3.4(2)(a)$ ) because it may be necessary to adduce witness evidence to assess this. However, given the reluctance of judges to undertake a mini-trial on a summary judgement application in order to determine whether the evidence can satisfy the requirements of the cause of action, ${ }^{138}$ it is unlikely that summary judgement will be granted on applications claiming that the claimant cannot demonstrate serious harm in all but the most obvious situations. The courts' approach, to take the claimant's pleaded facts and consider whether they disclose a cause of action, is unlikely to lead to summary judgement or strike out except in those cases where 'even if a party were to succeed in proving all the facts that he offers to prove he will not be entitled to the remedy that he seeks. ${ }^{139}$ Such an approach would be likely to reduce the number of claims removed from the court using procedural control mechanisms

However, this should not be the judicial approach. Judges should be willing to continue to use the flexibility offered by Jameel to manage cases that appear disproportionate to

138 See the criticisms of the approach to summary judgment taken in Three Rivers (No 3) by Adrian Zuckerman, 'A Colossal Wreck - the BCCI - Three Rivers Litigation' (2006) 25 Civil Justice Quarterly 287 which may lead to cases which can only be controlled by summary judgement to 'get out of control and absorb inordinate party and court resource' (303).

139 Three Rivers (No 3), above n38, per Lord Hope [95]. 
the reputational rights they seek to defend. If the court decides that it is possible (or, at least, not impossible) that the claimant will demonstrate 'serious harm', it can still consider whether the possibility of obtaining vindication through the continuance of a defamation action is limited, bearing in mind the resource limitations and the right to expression engaged by the case. In such a case the court should be willing and able to strike out a claim. Whilst it may be the case that the increase in the level of harm necessary to avoid a strike out under rule $3.4(2)(a)$ has an effect of reducing the need to engage with Jameel in some cases, it remains an important safeguard for the courts, insofar as they wish to control cases that come before them. It may, however, be that practitioners should take a belt and braces approach, and apply to strike out in the alternative under both rule $3.4(2)(a)$ and $3.4(2)(b)$.

\section{4 - Costs Management and Greater Proportionality}

A second set of changes that may alter the courts' approach to abuse of process applications are procedural, rather than substantive. Their case management powers have been altered following the Jackson review. ${ }^{140}$ These alterations may mean that it is possible to manage defamation cases to ensure that resources expended ware proportionate to the reputational vindication sought, and therefore it may be that fewer cases are seen as abuses and struck out on a Jameel basis. It is therefore necessary to briefly consider the new regime.

The new regime will provide clearer information to take into account when deciding whether to strike out. Parties to a multi-track case ${ }^{141}$ such as a claim in defamation, are

\footnotetext{
${ }^{140}$ Sir Rupert Jackson, Review of Civil Litigation Costs: Final Report (HMSO, 2009).

${ }^{141}$ CPRs rule 3.12 .
} 
required to file and exchange cost budgets once the defendant has filed a defence. ${ }^{142}$ Where a cost budget has not been filed, all costs, other than court fees, claimed by a successful party will be irrecoverable. ${ }^{143}$ The court may manage the parties proposed conduct of litigation as set out in the budgets in order to reduce the future costs. ${ }^{144}$ Once these budgets are set, CPRs rule $3.17(1)$ provides that 'when making any case management decision, the court will have regard to any available budgets of the parties.' A decision whether to strike out as an abuse is clearly a 'case management decision.' Therefore it may be easier to balance cost and reputational vindication. Where a budget is exceeded, the court will only allow recovery of these costs where there is a 'good reason' for the overrun. ${ }^{145}$ Therefore, parties will have a strong incentive to work within the filed budgets.

Cost management is not, however, a silver bullet that reduces the need for procedural control by the court. It may function to provide more information when the balancing exercise is carried out, but it cannot function to remove the need for a case management remedy for abuse of process. Whilst in some circumstance costs management under rule 3.15 may be used to reduce the costs of a claim, in order to render these costs proportionate to the reputational vindication sought, it is more likely, however, that a costs budget may allow the courts to focus more fully on the balance between interests which form the basis of a Jameel application. The budget may function to alert the court to a disproportionate burden on freedom of expression compared to the potential reputational vindication.

\footnotetext{
142 CPRs rule 3.13. For an exploration of the rules see Mr Justice Ramsey, 'Implementation of the Costs Reforms' (2013) 32 Civil Justice Quarterly 112.

${ }^{143}$ CPRs rule 3.14 and Mitchell v News Group Newspapers [2013] EWCA Civ 1537.

${ }^{144}$ CPRs rule 3.15

145 See Henry v NGN [2012] EWHC 90218 (Costs).
} 
Two further procedural developments could reduce the need for a Jameel strike out by ensuring that the resources devoted to the claim are proportionate to the reputational vindication sought, and to ensure that the claim does not unduly burden expressive rights. First, alternative dispute resolution could be encouraged. This would allow more creative solutions to the dispute to be reached, which have the potential to protect both reputation and expression, whilst dealing proportionately with the issues. The courts have sought to encourage parties to engage in mediation. ${ }^{146}$ This may amount to the 'firm exercise of the court's case management powers' that ensures a proper balance between competing interests contemplated in Ansari $v$ Knowles. ${ }^{147}$ However, mediation is voluntary, and it may fail. The mere existence of mediation, and sanctions for failure to mediate, does not relieve the court of the need to manage claims to ensure that a balance between public and private interests is reached.

Second, a power to allocate low value defamation claims to a (specialised) small claims track could be inserted into the CPRs. The lack of such a power has been identified as a reason that defamation claims are struck out as 'not worth the candle.' This would allow courts to dispose of the case at less cost to the public. Costs recovery for litigants using the small claims track is limited, ${ }^{148}$ with the defendant not liable for the claimant's costs in the event of a finding of liability, but also unable to recover his own costs if successful. The costs position does not, however, remove the burden on freedom of expression which will still be present, and Jameel applications will be needed to ensure that cases which do not have the potential to vindicate a valid reputational interest are quickly removed from courts

\footnotetext{
${ }^{146}$ Both Halsey v Milton Keynes General NHS Trust [2004] 1WLR 3002 and PGF II SA v OMFS Co [2013] EWCA Civ 1288 contemplate sanctions if a party unreasonably fails to take part in mediation.

147 Above n67, [23].

148 CPRs rule 29.14(2).
} 


\section{Conclusion}

This article has sought to argue for the importance of understanding procedure, and particularly Jameel strike out, when considering the balance between public and private interests, and reputation and expression, in defamation cases. It is argued that Jameel performs an important function, and will continue to perform an important function following the implementation of the Defamation Act 2013 and the new costs management rules. Courts should remain both able and willing to intervene. Summary judgment will retain an important, but subsidiary, role due to the limitations on evidential assessment.

In some cases the continued use of Jameel may leave a claimant subject to harmful untruths without a remedy, but this has always been the case with the defences applicable in defamation cases. The difficulty in obtaining vindication in certain cases where untruths have been published has been judged to be the price to be paid for the importance of freedom of expression. However, courts adjudicating on a Jameel strike out should particularly focus on the pleaded harm to reputation. Where reputation is capable of vindication the court should be slow to strike the claim out, but where it is not, the case will be an abuse, and should be struck out to support the right to freedom of expression guaranteed by the European Convention on Human Rights 